\title{
ILUSTRASI BUKU ENSIKLOPEDIA BURUNG RANGKONG DI INDONESIA
}

\author{
Andhika Putra Pradana ${ }^{1}$, Masnuna ${ }^{2}$ \\ 1,2Desain Komunikasi Visual, Fakultas Arsitektur Dan Desain, \\ Universitas Pembangunan Nasional "Veteran" Jawa Timur, \\ akung1945@gmail.com , masnuna.dkv@upnjatim.ac.id ${ }^{2}$
}

\begin{abstract}
Abstrak
Burung Rangkong atau Enggang yang dikenal juga sebagai 'petani hutan' memiliki peranan penting bagi hutan tropis di Indonesia, sebab kebiasaannya yang gemar menebar biji buah sisa makanannya saat ia terbang. Biji buah yang tersebar tersebut dapat menjadi bibit pohon baru dan dapat meregenerasi hutan secara alami. Namun, keberadaan burung tersebut jarang diketahui oleh masyarakat Indonesia. Padahal populasi burung tersebut di alam liar sangat mengkhawatirkan, hampir semua jenis Burung Rangkong memiliki status satwa yang dilindungi. Sangat disayangkan jika masyarakat khususnya anak-anak Indonesia di masa mendatang tidak mengenal burung yang sangat penting dan eksotis tersebut. Dibutuhkan media yang dapat memuat berbagai informasi dari Burung Rangkong dan menjadi media pengenalan yang menarik bagi anak-anak, maka buku ensiklopedia berilustrasi dipilih sebagai media utama pada penelitian ini. Terdapat 2 tahap yang digunakan dalam penelitian, yaitu tahap persiapan dan tahap penciptaan. Hasil dari penelitian ini menghasilkan konsep "Mengenal 'Petani Hutan' Indonesia", yang digunakan sebagai acuan untuk menciptakan media buku ensiklopedia berilustrasi dengan tujuan mengenalkan berbagai hal tentang Burung Rangkong beserta jenisnya tanpa harus bertemu atau melihat langsung burung tersebut di alam maupun di suaka marga satwa. Diharapkan Buku Ensiklopedia tersebut juga dapat menjaga eksistensi Burung Rangkong yang dilindungi.
\end{abstract}

Kata Kunci: Anak, Buku, Burung Rangkong, Ensiklopedia, llustrasi

\begin{abstract}
Hornbill is also known as 'forest farmers', has an important role in tropical forests in Indonesia, because of its habit of spreading the leftover seeds when it flies. The scattered fruit seeds can become new tree seedlings and can naturally regenerate the forests. However, the existence of these birds is rarely known by Indonesian society. Whereas the population of these birds in the wild is very worrying, almost all types of hornbills have protected animal status. It is unfortunate if society especially future Indonesian children do not recognize this very important and exotic bird. The Media that contain information about Hornbill is needed as an interesting knowledge medium for children, so the illustrated encyclopedia book was chosen as the main media in this research. In this research, there are 2 stages used which are the preparation stage and the stage of creation. The results of this study produced the concept of "Get to know Indonesia's Forest Farmers " which is used as a reference to create an illustrated encyclopedia book media to introduce various things about hornbill and their species without having to meet or see the bird directly in nature or wildlife reserves. It is expected that the encyclopedia book can maintain the existence of the protected hornbill.
\end{abstract}

Keywords: Children, Book, Hornbill, Encyclopedia, Illustration 


\section{PENDAHULUAN}

Indonesia merupakan negara kepulauan terbesar di dunia dengan iklim tropis. Indonesia adalah sebuah negara besar, yang mengalokasikan 120,6 juta hektar atau sekitar $63 \%$ dari luas daratannya sebagai Kawasan Hutan (Kementrian Lingkungan Hidup, 2018). Hal tersebut menjadikan Indonesia sebagai negara yang memiliki Sumber Daya Alam (SDA) yang melimpah. Berbagai jenis tumbuhan dan satwa hidup dalam hutan tropis di Indonesia. Hubungan timbal balik antara makhluk hidup dan alam sangat erat di Indonesia. Kekayaan alam hayati di Indonesia membuat banyak orang manfaatkannya untuk memenuhi kebutuhan hidup, pemanfaatan hasil hutan tersebut juga berdampak pada beberapa kasus pengerusakan hutan. Mulai dari kasus pembalakan liar, pembakaran lahan, hingga kasus perburuan satwa liar di hutan. Perburuan satwa liar di Indonesia marak terjadi. Data terbaru mengenai perburuan dan perdagangan ilegal satwa liar di Indonesia mencapai Rp. 13 triliun (Kementrian Lingkungan Hidup, 2018). Beberapa satwa yang diburu adalah satwa endemik yang menyandang status dilindungi karena sudah jarang sekali terlihat atau hampir mengalami kepunahan. Hal tersebut berakibat fatal pada keseimbangan ekosistem yang ada pada hutan tropis di Indonesia, karena setiap satwa memiliki peran yang sangat penting dalam menjaga ekosistem di hutan.

Salah satu satwa endemik yang marak diburu adalah Burung Rangkong. Rangkong merupakan burung yang masuk dalam keluarga Bucerotidae (julang, enggang, dan kangkareng), yang ditandai dengan ukuran tubuhnya dari $65 \mathrm{~cm}$ hingga $170 \mathrm{~cm}$. Beratnya juga bervariasi, dari 290 hingga 4.200 gram (Rhett A. Butler, 2019) Burung ini memiliki ciri khas pada bulu dan paruhnya yang unik. Burung Rangkong sangat berperan penting untuk hutan tropis di Indonesia. Dengan kemampuan terbangnya hingga rentang 100 kilometer persegi, burung ini dapat menebar biji sejauh jarak tempuh tersebut yang tanpa kita sadari, kegiatan meregenerasi hutan telah dilakukan oleh Rangkong (Rhett A. Butler, 2019). Burung Rangkong bersifat monogami yang berarti hanya memiliki 1 pasangan seumur hidup. Indonesia sendiri memiliki 13 spesies Burung Rangkong, tetapi semua spesies tersebut sudah menyandang status hampir punah dan dilindungi. Maraknya kasus perburuan liar Burung Rangkong di Indonesia sangatlah berpengaruh pada ekosistem hutan tropis di Indonesia. Umumnya Burung Rangkong diburu untuk diambil bulu dan paruhnya sebagai perhiasan, tak jarang Burung Rangkong diburu hanya untuk dijadikan koleksi peliharaan saja tanpa ada upaya konservasi. Hal tersebut juga didukung dengan pengetahuan masyarakat tentang status Burung Rangkong yang dilindungi, menurut hasil kuesioner yang dilakukan $79 \%$ masyarakat kurang mengerti jika Burung Rangkong dilindungi. Jika Burung Rangkong terus diburu maka bisa jadi burung tersebut akan mengalami kepunahan dalam waktu yang singkat.

Sangat disayangkan jika generasi selanjutnya tidak mengetahui akan keberadaan burung yang memiliki keunikan dan peran yang penting bagi hutan di Indonesia terlebih di masa yang akan datang. Dari hasil kuesioner yang dilakukan, $83 \%$ anak-anak tidak mengetahui tentang Burung Rangkong yang ada di Indonesia. Hal tersebut terjadi karena beberapa faktor salah satunya yaitu belum adanya buku yang berfokus pada pengenalan jenisjenis Burung Rangkong di Indonesia yang dibuktikan dengan hasil survei dari 5 toko buku 
yang telah penulis kunjungi. Hal tersebut membuat penulis bermaksud merancang buku buku ilustrasi ensiklopedia Burung Rangkong dan jenis-jenisnya yang ada di Indonesia. Anak usia 7-12 tahun atau usia Sekolah Dasar (SD) menjadi target audience utama buku tersebut. Menurut Samiudin (2017) sifat khas anak usia SD atau masa akhir kanak-kanak sangat realistik, ingin tahu, dan ingin belajar. Sebagian besar anak pada masa ini belum mampu memahami konsep-konsep abstrak. Pada usia tersebut dapat diartikan anakanak masih memiliki rasa ingin tahu yang tinggi sehingga mudah untuk mengenal sesuatu yang baru. Diharapkan sebagai generasi penerus, anak-anak tersebut dapat menjaga serta melestarikan populasi Burung Rangkong yang sudah jarang ditemukan.

Ensiklopedia merupakan kumpulan dari berbagai informasi dasar yang lengkap tentang sebuah ilmu pengetahuan. Ensiklopedia bisa dikatakan sebagai suatu karya universal yang ditujukan untuk meringkas secara komprehensif semua bidang pengetahuan, ilmu, teknologi, dan seni. Ensiklopedia juga dapat menjadi bahan acuan dalam mempelajari hal-hal tertentu. Pengetahuan yang disajikan dengan bahasa yang ringkas dan terstruktur dapat mempermudah seseorang untuk mempelajari hal-hal tersebut. Menurut (Nuraida \& Nisa, 2017) Terkait dengan kurikulum Pendidikan di Indonesia, buku ensiklopedia merupakan buku pengayaan yang memuat matari guna memperkaya buku teks pendidikan dasar, menengah hingga perguruan tinggi. Buku ensiklopedia dipilih mengingat ada 13 spesies Burung Rangkong yang ada di Indonesia maka media tersebut sangat tepat untuk mengemas pengetahuan tentang Burung Rangkong secara ringkas dan menarik dengan tambahan ilustrasi sebagai elemen pendukung.

Ilustrasi dipilih karena dari hasil wawancara dengan Yoki Hadiprakarsa selaku founder dari Rangkong Indonesia dan juga dari hasil Seminar Nasional Burung Rangkong yang diadakan di Universitas Gajah Mada mengatakan bahwa populasi dari beberapa spesies Burung Rangkong sudah terancam punah dan beberapa bersifat endemik di beberapa pulau saja, sehingga sangat sulit untuk mengabadikan secara digital gambar dari burung tersebut. Ilustrasi juga dipilih karena dari hasil wawancara dengan Nindia Nurmayasari selaku founder Klub Literasi Anak mengatakan bahwa ilustrasi sangat penting dalam buku anak, karena anak membutuhkan gambaran konkrit mengenai informasi yang baru diterimanya. Selain itu, menurut Nurgiyantoro (2018) Buku-buku yang ilustrasinya menarik akan merangsang rasa ingin tahu anak sehingga mampu membangkitkan motivasi untuk membacanya. Menurut Waites dan Daniel (dalam Gilang et al., 2018) Indikator kesesuaian konteks pada ilustrasi buku anak meliputi: (a) menggambarkan adegan penting yang terdapat dalam materi; (b) mewakili seluruh isi materi dalam bentuk yang utuh dan padat; (c) strategi penyampaian pesan melalui gambar dalam buku berulang-ulang untuk memudahkan daya ingat anak; (d) materi yang disampaikan dipertegas dengan gambar. Maka dari itu buku yang menggunakan ilustrasi sebagai elemen visual pendukung di dalamnya lebih mudah di mengerti oleh anak-anak. 


\section{METODE PENELITIAN}

Penelitian ini menggunakan dua tahapan yaitu tahap persiapan dan tahap penciptaan. Tahap Persiapan meliputi pengumpulan data, analisis data, sintesis, dan penentuan objek perancangan. Kemudian tahap penciptaan meliputi pra produksi, produksi dan pasca produksi. (Sugiyono, 2018)

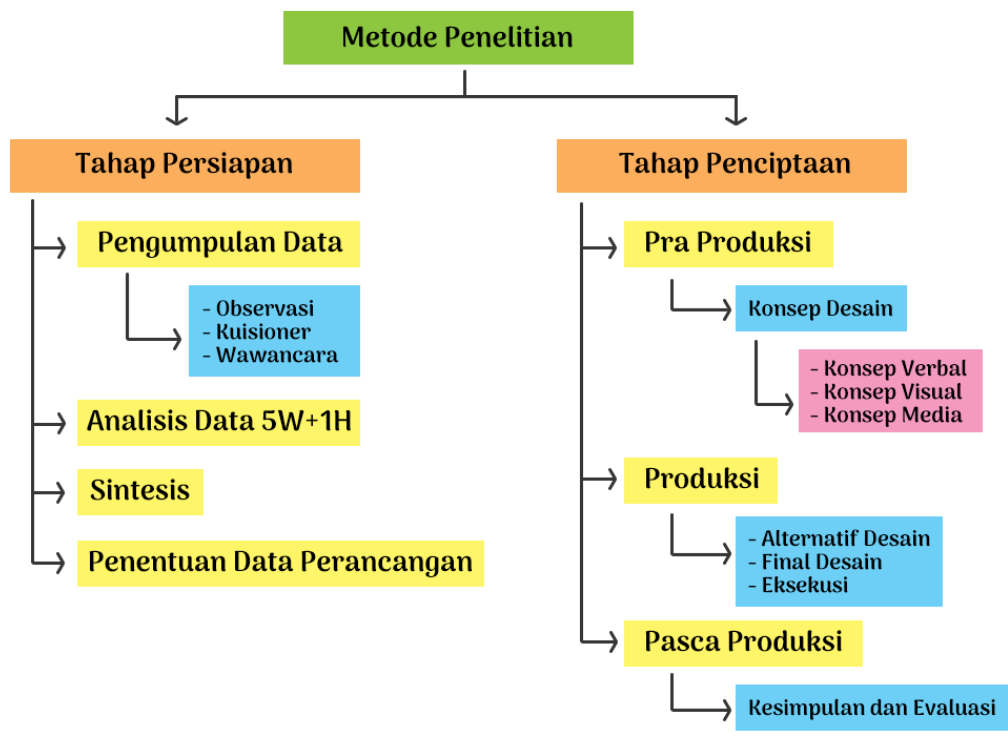

Gambar 1. Metode Penelitian

[Sumber: Data penulis]

\subsection{Tahap Persiapan}

\subsubsection{Pengumpulan Data}

Data merupakan bagian yang paling penting dalam proses penelitian. Data diperoleh melalui tiga metode yaitu:

1) Observasi; Metode ini merupakan proses pencatatan pola perilaku orang, benda atau kejadian yang sistematik tanpa adanya pertanyaan atau komunikasi dengan individuindividu yang diteliti (Yanty, 2017). Dalam penelitian ini metode observasi digunakan untuk mencatat dan mengamati fenomena tentang maraknya perburuan liar burung Rangkong yang dianggap penting karena menyebabkan status populasi burung tersebut menjadi (langkah) dan menimbulkan ketidak seimbangan ekosistem di hutan Indonesia serta antusiasme masyarakat khususnya anak-anak untuk mempelajari pengetahuan tentang burung Rangkong dan meninjau keberadaan media terkait dengan judul penelitian yang sudah ada. Hasil observasi tersebut digunakan untuk menarik kesimpulan belum ada atau tidaknya media yang memuat materi tentang ensiklopedia burung Rangkong di Indonesia khususnya untuk anak-anak usia sekolah dasar.

2) Kuesioner; Metode ini merupakan proses pengumpulan data dengan cara mendistribusikan pertanyaan dalam bentuk tulisan kepada responden yang telah ditentukan sebelumnya. Kuesioner dapat didistribusikan dengan dua cara, yaitu : (a) secara pribadi, diamana kuesioner diberikan sendiri oleh peneliti dan diisi secara pribadi oleh responden; dan (b) melalui pos, yaitu kuesioner yang diberikan kepada responden 
melalui pos (Yanty, 2017). Dalam penelitian ini metode kuesioner dilakukan dengan tujuan untuk mengetahui minat selera dan ketertarikan target audience terkait gambar atau visual yang akan diimplementasikan pada buku ensiklopedia yang akan dibuat. Anak sebagai target audience utama akan mengisi jawaban dari beberapa pilihan (gaya gambar dan jenis font) yang diberikan. Kuesioner akan dibagikan secara langsung kepada anak dengan cara bekerja sama dengan pihak sekolah dasar, sehingga anak bisa memilih secara langsung sesuai dengan yang mereka inginkan.

3) Wawancara; Metode ini merupakan proses pengumpulan data dengan mengajukan pertanyaan secara lisan kepada subjek yang telah ditentukan sebelumnya. Teknik wawancara dapat dilakukan secara langsung dengan bertatap muka antara responden dengan pewawancara. Selain dengan bertatap muka, wawancara dapat juga dilakukan melalui telepon (Yanty, 2017). Dalam Penelitian ini dilakukan metode wawancara mendalam secara langsung, yaitu peneliti mendatangi dan bertanya secara langsung kepada responden yang telah ditentukan guna menggali informasi secara lebih spesifik dan valid. Adapun narasumbernya yaitu (a) Yoki Hadiprakarsa selaku founder dari organisasi Rangkong Indonesia, data yang dicari yaitu untuk menggali informasi secara mendalam tentang ciri fisik, perilaku hidup, konservasi, dan kondisi terkini dari berbagai jenis burung Rangkong yang ada di Indonesia. Informasi tersebut penting bagi perancang sebagai bahan acuan untuk memuat konten dalam media yang akan dibuat. (b) Nindia Nurmayasari selaku founder Klub Literasi Anak, data yang dicari guna menggali informasi tentang bagaimana merancang buku ilustrasi untuk anak serta batasan muatan konten yang efektif untuk anak serta membantu perancang agar lebih mudah dalam menentukan gaya gambar yang cocok bagi target audience yang telah ditentukan.

\subsubsection{Analisis Data}

Analisis data merupakan proses mengolah data yang telah dikumpulkan sebelumnya menjadi lebih sederhana dan mudah dalam bentuk kesimpulan untuk dipahami guna menjawab permasalahan atau hipotesa yang dihasilkan dari fenomena yang ditemukan dan sebagai acuan utama bagi perancangan yang akan dibuat. Di samping itu kesimpulan disampaikan dalam bentuk pernyataan yang ketat dan padat sehingga tidak menimbulkan interpretasi lain (Unaradjan, 2019). Teknik analisis data yang digunakan dalam penelitian ini yaitu teknik $5 \mathrm{~W}+1 \mathrm{H}$ (What, Why, Where, When, Who, dan How) untuk menganalisis data yang telah dikumpulkan sebelumnya menjadi lebih sederhana dan memudahkan perancang dalam menemukan solusi dari fenomena atau permasalahan terkait dengan perancangan yang diangkat.

\subsubsection{Sintesis}

Sintesis merupakan kesimpulan hasil dari analisis data yang telah dilakukan. Sintesis berupa keyword dengan adanya sintesis maka proses pencarian keyword akan lebih mudah. Sintesis juga digunakan untuk membuat konsep desain sebagai acuan untuk merancang media yang akan dibuat. 


\subsubsection{Objek Perancangan}

Pada Perancangan ini media yang digunakan yaitu buku ensiklopedia untuk anak usia sekolah dasar (7-12 tahun) yang membahas tentang ciri-ciri fisik, habitat, perilaku hidup, hingga status konservasi dari berbagai jenis burung Rangkong yang ada di Indonesia disertai dengan ilustrasi secara realis. Tujuan dari perancangan ini yaitu mengedukasi dan menambah wawasan anak tentang dunia satwa khususnya burung Rangkong. Ilustrasi digunakan karena berdasarkan hasil wawancara dan kondisi konservasi burung Rangkong yang semakin sulit ditemui di alam, sedangkan gambaran secara visual sangat penting guna memberikan gambaran konkrit tentang burung Rangkong. Penyampaian materi juga disampaikan dengan gaya bahasa yang sederhana dan ringan sehingga mudah dimengerti oleh target audience.

Target audience dari perancangan ini meliputi; 1) Demografis yaitu Laki-laki dan perempuan dengan rentang usia 7-12 tahun, memiliki status sebagai pelajar sekolah dasar, 2) Psikografi yaitu suka menyukai hewan, suka membaca buku, tertarik dengan hal kreatif, atau sejenisnya, 3) Geografis yaitu audience yang hidup di perkotaan di Indonesia.

\subsection{Tahap Penciptaan}

\subsubsection{Pra Produksi}

Pada Perancangan ini tahap pra produksi berguna untuk menyusun konsep desain yang berasal dari proses mind mapping sebagai acuan dasar untuk menciptakan perancangan yang sesuai dengan tujuan dan sintesis data. Konsep desain yang disusun meliputi konsep verbal, konsep visual, dan konsep media. Konsep verbal berisi tentang strategi komunikasi, gaya bahasa yang digunakan, pemilihan judul, dan sinopsis. Konsep visual berisi tentang gaya ilustrasi, acuan warna, pemilihan layout dan tipografi. Sedangkan, konsep media berisi tentang spesifikasi media utama yang digunakan seperti ukuran, isi materi, jumlah halaman, bahan yang digunakan, dan harga penjualan. Terdapat juga pemilihan media pendukung beserta strategi promosi yang digunakan.

\subsubsection{Produksi}

Tahap ini merupakan tahap membuat media utama perancangan dengan mengacu pada konsep desain yang telah ditentukan di tahap pra produksi. Pembuatan alternatif desain berfungsi sebagai pilihan yang akan diberikan kepada target audience sebelum diterapkan pada media utama dalam perancangan. Evaluasi desain dilakukan untuk menyaring desain yang telah dihasilkan dari alternatif desain terpilih untuk dikembangkan dan diperbaiki agar sesuai untuk diimplementasikan pada media utama perancangan yang akan dibuat. Setelah terpilih desain yang sesuai tahap selanjutnya yaitu tahap eksekusi, proses produksi hasil desain hingga menjadi media utama yang siap untuk dipublikasikan kepada target audience.

\subsubsection{Pasca Produksi}

Tahap pasca produksi dilakukan untuk membuat kesimpulan dan evaluasi guna mengetahui kekurangan dan kelebihan yang ada pada perancangan ini. Sehingga hasil dari kesimpulan dan evaluasi tersebut berguna sebagai acuan perancangan berikutnya. 


\section{HASIL DAN PEMBAHASAN}

\subsection{Tahap Persiapan}

\subsubsection{Hasil Pengumpulan Data}

Setelah melakukan observasi diperoleh data bahwa keadaan Burung Rangkong di Indonesia sangat mengkhawatirkan dari 13 jenis Burung Rangkong yang tersebar hampir semua jenis memiliki status dilindungi, dengan status yang paling kritis yaitu jenis burung Rangkong Gading. tentang upaya konservasi yang saat ini dilakukan terbagi menjadi dua jenis yaitu konservasi insitu dan eksitu. Konservasi insitu yaitu konservasi yang dilakukan secara langsung di habitat aslinya yaitu di beberapa taman nasional yang ada di Indonesia, sedangkan konservasi eksitu yaitu konservasi yang dilakukan di luar habitat aslinya yaitu di eco green park, kebun binatang, dan taman safari.

Pada konservasi insitu kendala yang ada yaitu dari berkurangnya pohon purba yang memiliki lubang alami yang menjadi kriteria sarang dari burung Rangkong. Sedangkan pada beberapa di konservasi eksitu hanya beberapa jenis saja yang terdapat pada konservasi jenis ini. Lahan yang digunakan pun cukup terbatas dengan sarang buatan yang kurang sesuai sehingga mempengaruhi kualitas reproduksi dari burung Rangkong. hal ini membuktikan bahwa memang dibutuhkan media edukasi lain selain taman konservasi eksitu yang dapat mengedukasi masyarakat khususnya anak-anak tentang burung Rangkong tanpa menyita hak burung Rangkong itu sendiri untuk hidup bebas di alam.

Namun, pada beberapa toko buku anak yang dikunjungi peneliti, sulit ditemukan buku yang mengangkat materi pengetahuan tentang burung Rangkong, materi didominasi oleh pengetahuan tentang hewan populer dan lebih banyak menggunakan bahasa asing sehingga sulit dipahami oleh anak-anak di Indonesia. Setelah menyebarkan 100 kuesioner kepada responden, diperoleh data sebagai berikut yaitu a) $83 \%$ anak tidak mengetahui burung Rangkong. b) $44 \%$ anak menyukai gaya ilustrasi realis menggunakan digital painting yang tidak terlalu detail. c) $41 \%$ anak menyukai jenis huruf dekoratif. d) 75\% anak cenderung lebih menyukai layout buku yang didominasi oleh ilustrasi daripada teks.

Menurut hasil wawancara dengan Yoki Hadiprakarsa selaku founder dari organisasi Rangkong Indonesia, menyatakan bahwa mengingat peran burung Rangkong yang sangat penting dalam ekosistem hutan tropis di Indonesia dan populasinya yang sangat mengkhawatirkan maka dari itu pengetahuan tentang burung Rangkong memang penting untuk diketahui oleh masyarakat khususnya anak-anak karena mereka adalah generasi penerus yang akan menjaga dan melestarikan burung Rangkong yang sangat penting bagi ekosistem hutan di Indonesia. Hal tersebut didukung dengan hasil wawancara dengan Nindia Nurmayasari selaku founder Klub Literasi Anak, yang menyatakan bahwa materi tersebut sangat cocok disajikan dalam bentuk buku ensiklopedia anak yang di dalamnya terdapat elemen ilustrasi sebagai pendukung untuk menyampaikan pesan dari buku tersebut. Ilustrasi dengan tampilan semirip mungkin dengan aslinya adalah ilustrasi yang cocok untuk buku ensiklopedia. Penyampaian pesan 
secara ringkas dan kreatif dapat menarik dan memudahkan anak dalam memahami isi buku.

\subsubsection{Hasil Analisis Data}

Data yang telah dikumpulkan selanjutnya dianalisis menggunakan teknik $5 \mathrm{~W}+1 \mathrm{H}$ (What, Why, Where, When, Who, dan How) dan diperoleh hasil sebagai berikut:

1) What; Masalah apa yang sedang terjadi saat ini. Masalah yang terjadi dalam penelitian ini yaitu dari hasil kuesioner diketahui bahwa banyak masyarakat khususnya anak-anak yang belum atau tidak mengetahui tentang Burung Rangkong dan manfaatnya yang penting bagi kelestarian hutan di Indonesia.

2) Why; Mengapa masalah ini bisa terjadi. Populasi Burung Rangkong yang kian memprihatinkan akibat banyaknya perburuan liar dan kurangnya perhatian dari masyarakat Indonesia mengakibatkan burung ini jarang diketahui oleh anak-anak.

3) Where; Dimana masalah tersebut terjadi. Masalah tersebut terjadi di hampir seluruh wilayah di Indonesia, khususnya anak-anak yang tinggal di perkotaan yang sulit untuk menjumpai burung tersebut di habitat aslinya.

4) When; Kapan masalah tersebut muncul. Masalah ini muncul ketika orang tua khususnya yang tinggal di perkotaan besar memiliki jadwal yang sibuk, sehingga tidak memiliki waktu untuk mengajak dan mengenalkan anak tentang Burung Rangkong di habitatnya maupun di suaka marga satwa.

5) Who; Siapa yang menjadi target audience dalam penelitian ini. Berdasarkan hasil wawancara dan kuesioner didapatkan bahwa target audience pada penelitian ini yaitu anak-anak usia sekolah dasar (7-12 tahun) yang memiliki demografis tinggal di perkotaan besar karena mereka memiliki sedikit kesempatan untuk menjumpai secara langsung burung tersebut di habitat aslinya maupun di suaka marga satwa.

6) How; Bagaimana solusi yang tepat untuk menyelesaikan masalah tersebut. Masyarakat yang tinggal di perkotaan memiliki kepadatan jad wal yang tinggi sehingga mereka memilih cara praktis untuk membantu mereka dalam hal mendidik dan memberikan wawasan ilmu pengetahuan kepada anak. Salah satu hal tersebut dengan memberikan buku yang berisi ilmu pengetahuan sebagai bahan bacaan kepada anak, tetapi bagaimana buku itu bisa menarik perhatian anak untuk membaca? Secara harfiah anak lebih tertarik dengan buku yang memiliki banyak gambar daripada buku yang memuat banyak teks. Untuk itu dalam permasalahan ini perlu dirancang buku ensiklopedia ilustrasi tentang jenis burung Rangkong yang ada di Indonesia sebagai media edukasi bagi anak untuk mengenal satwa tersebut tanpa harus meluangkan waktu untuk datang langsung ke habitat aslinya di hutan tropis yang ada Indonesia. Buku ensiklopedia ini berisi informasi mengenai pengetahuan dasar seperti ciri-ciri fisik, habitat, perilaku hidup, serta fakta unik dari berbagai jenis burung Rangkong yang ada di Indonesia. melalui buku ensiklopedia ini diharapkan masyarakat Indonesia khususnya anak-anak dapat mengenal salah satu satwa unik yang penting bagi hutan tropis di Indonesia tersebut.

Hasil dari analisis data menggunakan teknik $5 \mathrm{~W}+1 \mathrm{H}$ menyebutkan bahwa banyak masyarakat yang belum dan tidak mengetahui tentang keberadaan Burung Rangkong dan manfaatnya yang penting bagi hutan tropis di Indonesia. Hal tersebut terjadi karena 
populasi burung Rangkong yang kian berkurang karena perburuan liar dan berkurangnya habitat alami dari burung tersebut sehingga sangat sulit untuk dijumpai. Anak-anak menjadi yang sangat dirugikan dalam hal ini, khususnya yang tinggal di perkotaan besar mereka sangat sulit untuk mengenal burung tersebut secara langsung. Jadwal aktivitas orang tua mereka yang padat sehingga tidak memiliki waktu untuk mengajak dan mengenalkan anak tentang Burung Rangkong di habitatnya maupun di suaka marga satwa. Maka dari itu diperlukan alternatif media lainnya yang dapat memberikan informasi dan pengetahuan tentang burung Rangkong. Buku ensiklopedia dipilih karena mampu memuat berbagai informasi terkait suatu objek di dalamnya tentunya dikemas secara menarik agar mampu membuat anak-anak tertarik untuk membacanya. Untuk itu perlu dirancang buku ensiklopedia dengan ilustrasi yang menarik di dalamnya dengan gaya penyampaian bahasa yang ringan dan sederhana sehingga mampu dipahami oleh anak. Buku tersebut sebagai alternatif media edukasi bagi anak untuk mengenal burung Rangkong tanpa harus meluangkan waktu untuk datang langsung ke habitat aslinya di hutan tropis yang ada Indonesia atau pun ke taman marga satwa.

\subsubsection{Sintesis}

Berdasarkan analisis yang telah dilakukan, dapat ditarik kesimpulan atau sintesis, bahwa burung Rangkong penting untuk diketahui dan dikenal oleh masyarakat luas khususnya anak-anak, mengingat burung tersebut yang penting bagi ekosistem hutan di masa mendatang dan kondisinya yang sudah terancam punah di alam. Untuk itu diperlukan media informasi yang dikemas secara kreatif, menarik, dan mudah dipahami oleh anakanak dalam jangka waktu yang lama. Dari data kuesioner dan wawancara buku ensiklopedia menjadi media yang tepat karena dapat memuat banyak informasi di dalamnya. Konten dalam buku membahas tentang ciri fisik, perilaku, dan status konservasi dari burung Rangkong yang disampaikan dengan bahasa yang ringan dan sederhana, serta menggunakan bahasa Indonesia. Hal tersebut bertujuan agar memudahkan anak dalam belajar mandiri karena anak dapat memahami dan mengingat isi buku tanpa didampingi orang tua. Ilustrasi dan warna digunakan sebagai elemen pendukung penyampaian materi dan agar menarik perhatian anak untuk membaca isi buku. Ilustrasi menggunakan teknik digital painting dengan gaya gambar realis agar anak dapat membayangkan bentuk asli dari burung tersebut. Sedangkan untuk warna menurut hasil riset burung Rangkong memiliki warna bulu dominasi hitam dan warna mencolok seperti kuning, biru, dan merah di beberapa bagian tubuh, maka warna dalam buku akan didominasi dengan warna hitam dan warna mencolok. Layout yang digunakan disusun secara sederhana menggunakan single grid column dan double grid column agar memudahkan anak-anak dalam membaca isi buku.

\subsection{Tahap Penciptaan}

\subsubsection{Konsep Desain}

Setelah menganalisis semua data yang diperoleh dan didapatkan hasil kesimpulan atau sintesis. Tahapan berikutnya yaitu menentukan keyword yang berguna sebagai acuan untuk mengkomunikasikan sebuah pesan yang ingin disampaikan dalam perancangan sehingga sesuai dengan tujuan yang ingin dicapai dalam perancangan tersebut. 
Keyword dihasilkan dari proses mind mapping yang telah dilakukan sebelumnya, terdapat kata yang menjadi acuan visual maupun verbal yang kemudian dirangkai menjadi suatu keyword yaitu "Mengenal 'Petani Hutan' Indonesia”. Keyword tersebut didasari dengan tujuan memberikan informasi kepada target audience secara informatif, menarik dan kreatif tentang perilaku, ciri khas, serta keadaan konservasi dari berbagai jenis burung Rangkong yang ada di Indonesia dengan cara merancang buku ensiklopedia ilustrasi jenis Rangkong yang ada di Indonesia dengan bahasa yang ringan serta mudah dipahami. Kategori ensiklopedia dikelompokkan dari status konservasi mulai dari yang beresiko sangat terancam hingga berpotensi terancam, agar mudah untuk diingat dan dimengerti. Tipografi yang digunakan yaitu jenis huruf dekoratif yang kemudian disesuaikan dengan studi tipografi dari bentukan burung Rangkong, serta tetap memperhatikan readibility dan legibility. Layout yang digunakan lebih menonjolkan elemen visual berupa ilustrasi realis dengan teknik digital painting yang dipadukan dengan dominasi warna hitam dan mencolok agar warnanya kontras sesuai dengan warna bulu dari Burung Rangkong agar mudah dipahami serta guna menarik perhatian target audience untuk membaca.

Berdasarkan makna denotasinya, keyword "Mengenal Petani Hutan Indonesia" dapat diartikan sebagai berikut; kata mengenal berarti suatu tindakan atau proses guna mengetahui ciri-ciri dari objek tanpa harus bertemu atau bersinggungan secara langsung dengan objek tersebut. Kata petani didefinisikan sebagai suatu individu yang mengolah lahan untuk menghasilkan bahan pangan bagi diri sendiri dan individu lain untuk keperluan hidup sehari-hari. Kata hutan didefinisikan sebagai suatu kesatuan ekosistem berupa hamparan lahan berisi sumber daya alam hayati yang didominasi pepohonan dalam persekutuan alam lingkungannya, yang satu dengan yang lainnya tidak dapat dipisahkan (UU 41/1999). Kata Indonesia merupakan nama negara kepulauan di Asia Tenggara.

Sedangkan secara konotasi keyword "Mengenal Petani Hutan Indonesia" diartikan sebagai upaya untuk mengetahui dan mempelajari berbagai hal tentang burung Rangkong yang dikenal juga sebagai petani hutan di Indonesia tanpa harus bertemu atau melihat langsung burung tersebut di alam maupun di taman marga satwa. Dikenal sebagai petani hutan karena kebiasaan burung Rangkong yang suka menyebar biji pohon sisa pencernaan saat mereka terbang menjelajah di habitat aslinya di hutan tropis Indonesia. Keyword tersebut dipilih sesuai dengan tujuan perancangan yaitu target audience dapat mengenal (mengetahui berbagai hal) tentang burung Rangkong secara mandiri tanpa bantuan orang tua.

\subsubsection{Konsep Verbal}

Strategi komunikasi dari konsep verbal dalam perancangan buku ilustrasi ensiklopedia jenis-jenis burung Rangkong yang ada di Indonesia adalah terletak pada gaya penyampaiannya yang menambahkan konten informasi berupa fakta-fakta dari burung Rangkong yang dimuat berdasarkan $5 \mathrm{~W}+1 \mathrm{H}$ dalam Bahasa Indonesia (apa, dimana, kapan, mengapa, siapa, bagaimana) untuk menambah pengetahuan target audience. Bahasa yang digunakan menggunakan bahasa yang ringan dan singkat menggunakan 
Bahasa Indonesia, serta tipografi yang digunakan yaitu jenis huruf dekoratif yang kemudian disesuaikan dengan studi tipografi dari bentukan burung Rangkong, serta tetap memperhatikan keterbacaan dan kejelasan agar tujuan pesan yang ingin disampaikan mudah untuk dipahami dan diingat dengan jelas.

Judul buku mengacu pada keyword yang terpilih, "Mengenal Petani Hutan Indonesia" yang berarti suatu upaya mengetahui segala hal tentang burung Rangkong yang ada di Indonesia. Maka judul dari buku ini yaitu "Ensiklopedia Rangkong Indonesia", serta subjudul dari buku ini yaitu "Mengenal Jenis-Jenis burung Rangkong di Indonesia" supaya anak bisa dengan mudah mengingat dan memahami materi yang dimuat dalam buku tersebut.

\subsubsection{Konsep Visual}

Berdasarkan hasil kuesioner dan wawancara didapatkan konsep visual sebagai berikut; a) ilustrasi yang digunakan pada buku akan menggunakan gaya realis dan naturalis menggunakan teknik digital painting mengikuti dari keyword "Mengenal Petani Hutan Indonesia" maka di dalam buku ini terdapat ilustrasi dari burung Rangkong serta suasana hutan tropis sebagai environment pendukung agar anak dapat lebih mengerti tentang burung Rangkong di habitat aslinya. Pembuatan ilustrasi akan menggunakan acuan visual dengan sample objek dari gambar foto menjadi bentuk ilustrasi yang semirip mungkin dengan objek tersebut. b) Warna yang digunakan dalam perancangan buku ilustrasi ensiklopedia jenis-jenis burung Rangkong di Indonesia mengacu pada hasil riset burung Rangkong memiliki warna bulu dominasi hitam dan warna mencolok seperti kuning, biru, dan merah di beberapa bagian tubuh, maka warna dalam buku akan didominasi dengan warna hitam dan warna mencolok agar warnanya kontras seperti warna bulu burung Rangkong.

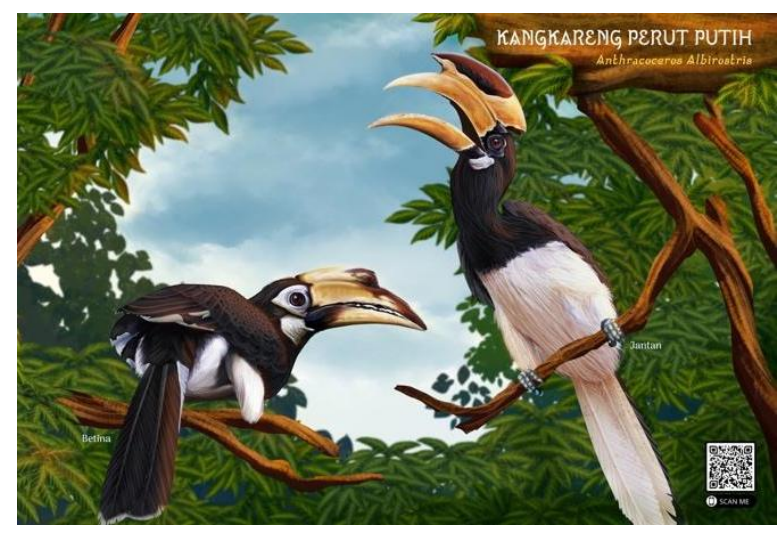

Gambar 2. Contoh Ilustrasi

[Sumber: Data penulis]

c) Perancangan buku ensiklopedia ilustrasi jenis-jenis Rangkong di Indonesia ini menggunakan komposisi single grid column dan double grid column, bervariasi namun tetap memperhatikan prinsip-prinsip dalam layout. seperti sequence/urutan, emphasis/penekanan, balance/keseimbangan, dan unity/kesatuan. Sehingga dapat menghasilkan buku dengan layout yang sistematis, sesuai dengan target audience. d) 
Buku ilustrasi ini akan menggunakan jenis huruf dekoratif agar menarik perhatian anakanak dengan tetap memperhatikan keterbacaan dan kejelasan agar tujuan pesan yang ingin disampaikan mudah untuk dipahami dan diingat dengan jelas. Jenis huruf yang dipilih mengacu pada bentukan dari paruh burung Rangkong yang cenderung runcing dan melengkung di bagian ujungnya, maka dipilih font bernama Wizzta dengan ukuran 40, 36, 24.5 untuk diimplementasikan pada judul buku. Sedangkan, font yang digunakan untuk isi konten menggunakan font Arima Madurai (semi bold) dengan ukuran 21 dan $13 \mathrm{pt}$.

\subsubsection{Konsep Media}

Media utama berupa buku ilustrasi ensiklopedia jenis-jenis burung Rangkong yang ada di Indonesia memiliki tujuan untuk mengedukasi target audience yaitu anak-anak usia sekolah dasar (7-12 tahun) tentang jenis-jenis burung Rangkong yang ada di Indonesia. Konten yang dimuat mulai dari ciri-ciri fisik, habitat, perilaku hidup, hingga status konservasi dari berbagai jenis burung Rangkong yang ada di Indonesia. Buku terdiri dari 98 halaman dan dijilid menggunakan teknik soft cover, hal tersebut bertujuan supaya buku mudah dibawah oleh anak dan untuk menekan harga agar lebih ergonomis. Terdapat ilustrasi sebagai elemen pendukung penyampaian materi dan agar menarik perhatian anak-anak untuk membaca. Disusun berdasarkan status konservasi burung tersebut yaitu mulai dari yang memiliki risiko sangat terancam hingga berpotensi terancam, agar mudah untuk diingat dan dimengerti oleh anak-anak betapa pentingnya burung Rangkong bagi hutan di Indonesia. Terdapat tambahan konten berupa halaman teka-teki silang yang memuat 5 pertanyaan seputar jenis burung Rangkong yang telah dijelaskan di halaman sebelumnya, konten teka-teki silang ini bertujuan untuk mengasah seberapa paham anak-anak tentang jenis burung Rangkong yang telah dibaca.

Selanjutnya terdapat halaman berisi poster yang dapat disobek untuk ditempelkan pada dinding kamar, poster tersebut terdiri dari gambar sepasang dari satu jenis burung Rangkong yang dijelaskan pada halaman sebelumnya. Poster tersebut berguna untuk memudahkan anak-anak menghafal bentuk dan ciri-ciri dari jenis-jenis burung Rangkong. Terdapat juga halaman untuk mewarnai dari jenis-jenis burung Rangkong, konten mewarnai berguna untuk mengasah kreatifitas anak agar dapat membayangkan wujud dan warna burung Rangkong sesuai dengan imajinasi mereka. Untuk lebih menarik minat anak-anak dalam mengisi teka-teki silang dan mewarnai, maka akan diadakan kompetisi tiap minggunya melalui akun sosial media, 5 jawaban teka-teki silang yang benar dan 5 hasil mewarnai terbagus akan mendapatkan merchandise sehingga hal tersebut juga dapat melatih jiwa kompetitif pada anak.

\subsubsection{Proses Desain}

Setelah menentukan konsep desain sebagai acuan, peneliti kemudian membuat desain visual. Desain yang diciptakan, kemudian dikembangkan lagi agar sesuai dengan keyword hingga terpilih desain utama yang akan diimplementasikan di dalam buku Ensiklopedia Rangkong Indonesia. 
1) Desain Judul Buku. Judul buku menggunakan jenis huruf dekoratif sesuai dengan hasil kuesioner dan agar menarik perhatian anak-anak dengan tetap memperhatikan keterbacaan dan kejelasan dengan tujuan pesan yang ingin disampaikan mudah untuk dipahami dan diingat dengan jelas. Jenis huruf yang dipilih menggunakan studi anatomi huruf dengan mengacu pada bentukan dari paruh burung Rangkong yang cenderung runcing dan melengkung di bagian ujungnya.

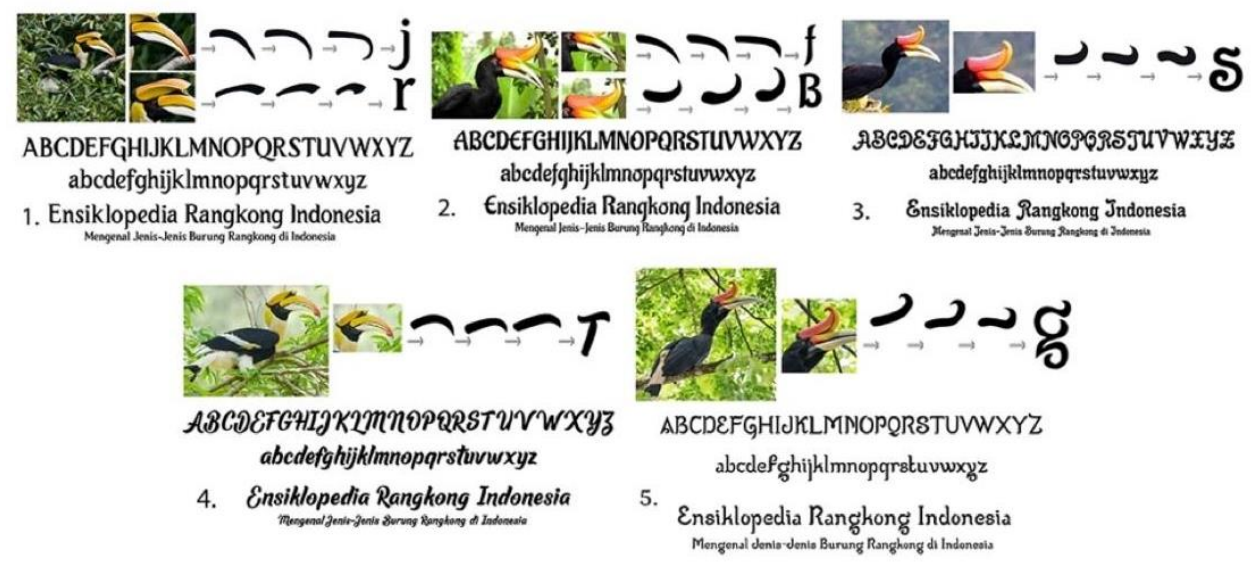

Gambar 3. Alternatif Judul Buku

[Sumber: Data penulis]

Desain terpilih dari alternatif di atas yaitu font bernama Wizzta dengan ukuran 40, 36, 24.5 untuk diimplementasikan pada judul buku.

\section{ENSIKLOPEDIA RANGKONG INIDONESIA \\ Mengenal denis-denis Burung Rangkong di Indonesia}

Gambar 4. Desain terpilih Judul Buku

[Sumber : Data Penulis]

2) Desain Cover Buku. Cover buku terdiri dari ilustrasi burung Rangkong dan environment hutan dengan warna yang yang semirip mungkin dengan warna aslinya, serta menerapkan prinsip layout buku pada cover sehingga membuat pembaca semakin tertarik untuk membaca bukunya.
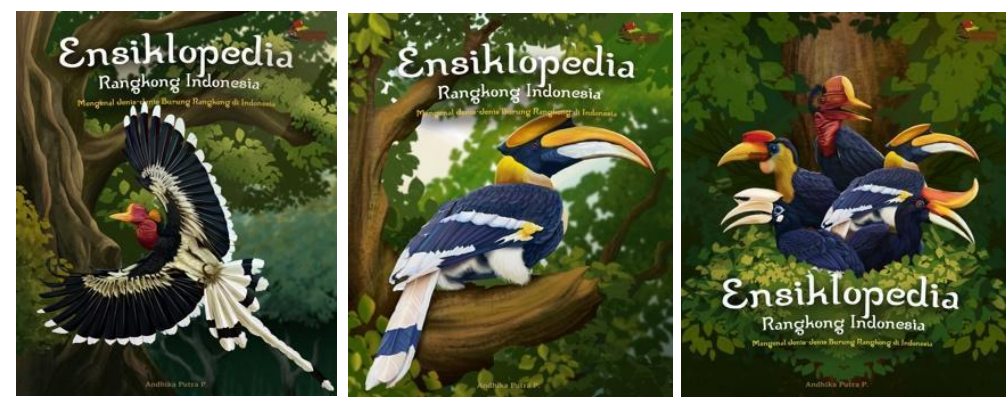

Gambar 5. Desain terpilih Judul Buku

[Sumber: Data penulis] 
Alternatif desain cover pertama terdapat ilustrasi seekor Rangkong Gading, Rangkong Gading dipilih karena burung tersebut merupakan jenis Burung Rangkong yang status konservasinya kritis dan mendekati angka kepunahan. Pose saat terbang dipilih untuk memperlihatkan keindahan dari Rangkong Gading dengan latar belakang hutan hujan yang menjadi habitat mayoritas dari burung Rangkong. Alternatif desain cover kedua terdapat ilustrasi seekor Enggang Papan, Enggang Papan dipilih karena burung tersebut merupakan Burung Rangkong yang memiliki daya jelajah yang paling luas hingga di beberapa negara. Sedangkan untuk alternatif desain cover yang ketiga terdapat ilustrasi dari beberapa jenis burung Rangkong, hal tersebut untuk menerangkan isi dari buku yang membahas tentang berbagai jenis burung Rangkong yang ada di Indonesia.

3) Desain Supergrafis. Supergrafis buku merupakan ilustrasi dari beberapa elemen yang ada di hutan tropis seperti potongan kayu, dedaunan dan juga siluet hutan yang berguna untuk membuat tatanan layout pada buku menjadi semakin menarik.
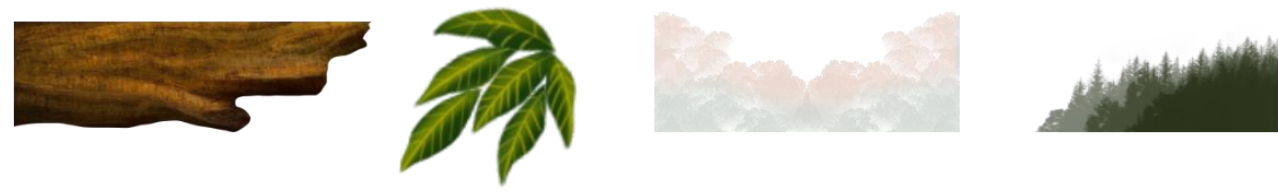

Gambar 6. Desain Supergrafis

[Sumber: Data penulis]

\subsubsection{Final Project}

Setelah menemukan desain yang sesuai dengan keyword perancangan, kemudian desain yang terpilih diterapkan pada media utama dalam perancangan. Pada tahap akhir ini media utama sudah siap untuk diproduksi dan dipublikasikan secara luas kepada target audience yaitu anak-anak usia sekolah dasar.
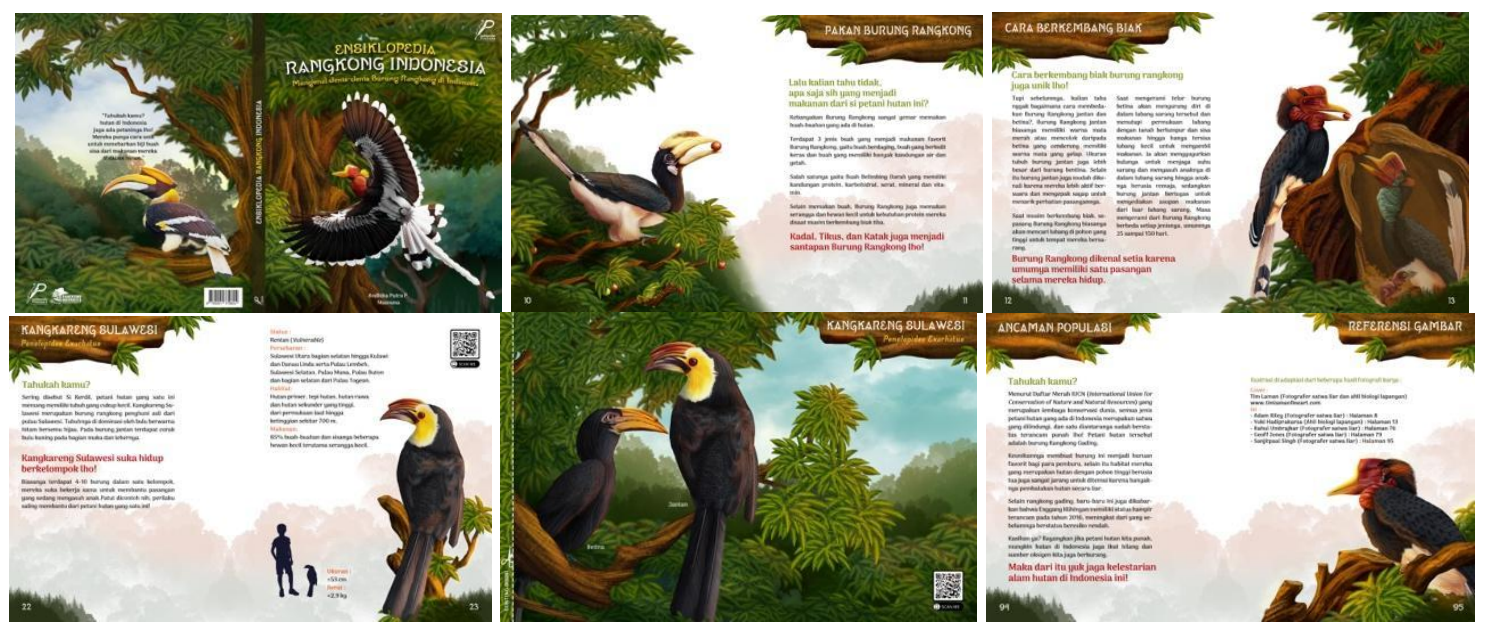

Gambar 7. Desain isi Buku

[Sumber: Data penulis] 


\subsubsection{Eksekusi}

Setelah itu desain final akan dicetak menjadi media utama yaitu buku. Buku terdiri dari 98 halaman yang dicetak menggunakan kertas Green Forest Smooth dengan gramatur 150 gsm berwarna putih agar hasil cetakan tidak mudah pecah saat terlipat dan supaya ringan untuk di bawah serta ergonomis dari segi biaya produksi. Buku ini akan cetak dengan mesin digital printing indigo dan dijilid softcover agar lebih ergonomis dari segi biaya produksi dan supaya ringan untuk dibawah oleh target audience. Jika dicetak dengan mesin offset maka buku ini akan dijual dengan harga sekitar Rp. 150.000,mengingat jumlah halaman, bahan dan proses cetak yang digunakan untuk membuat buku.

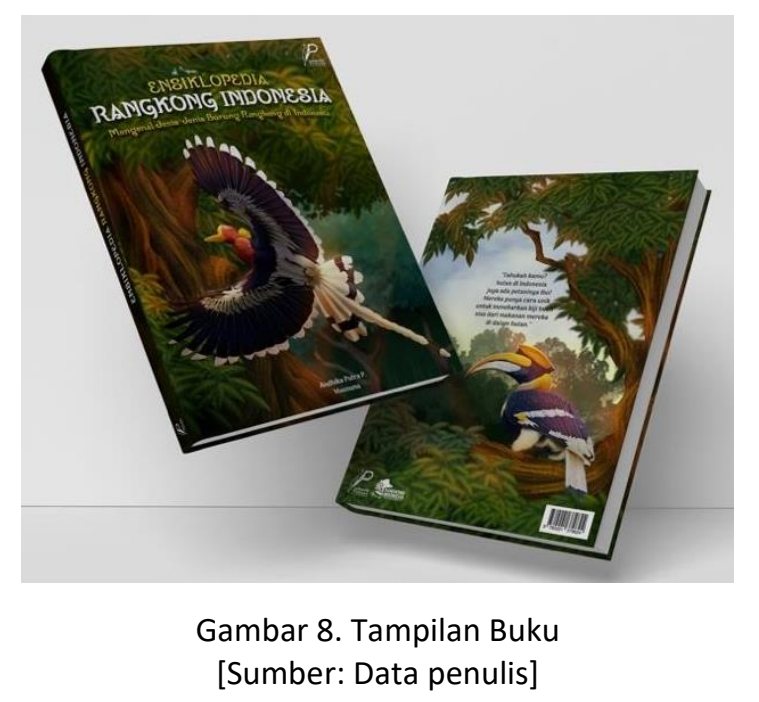

\section{KESIMPULAN}

Buku Ensiklopedia Rangkong Indonesia dirancang untuk memudahkan anak-anak khususnya yang berusia sekolah dasar agar bisa mengetahui dan mengenal jenis-jenis burung Rangkong yang ada di Indonesia. Anak-anak dapat mengenal burung yang sangat penting dalam menjaga ekosistem hutan tropis di Indonesia ini tanpa harus menjumpainya langsung di habitat aslinya maupun di suaka marga satwa, sehingga burung tersebut bisa bebas tinggal di habitatnya. Terdapat berbagai konten menarik yang bisa mengasah pemahaman anak akan Burung Rangkong seperti konten teka-teki silang dan konten mewarnai, terdapat juga poster yang dapat disobek dan ditempelkan pada dinding kamar agar anak mudah mengingat berbagai jenis burung Rangkong yang ada.

Bagi keilmuan Desain Komunikasi Visual, buku ensiklopedia ini dapat menjadi acuan dalam mendesain media pembelajaran yang menarik dan menambah pengetahuan tentang gaya gambar yang tepat untuk mendukung materi yang dimuat. Selanjutnya, bagi penelitian yang akan datang ada media lain yang dapat mengenalkan satwa-satwa eksotik yang jauh dari jangkauan manusia lainnya agar anak-anak memiliki wawasan yang luas tentang satwa di bumi tercinta ini. Contohnya seperti, aplikasi android yang bisa diakses secara online dan offline, karena tidak menutup kemungkinan sistem 
pembelajaran di masa yang akan datang akan lebih praktis sehingga anak-anak bisa mengetahui isi dunia tanpa keluar rumah dan biaya yang mahal.

\section{UCAPAN TERIMA KASIH}

Penulis menyampaikan terima kasih kepada Yoki Hadiprakarsa selaku founder Rangkong Indonesia beserta tim yang telah banyak membantu dalam memberikan informasi terkait penelitian ini, kemudian terimakasih juga disampaikan kepada Nindia Nurmayasari selaku founder Klub Literasi Anak yang sudah bersedia menjadi narasumber terkait dengan penelitian ini dan semua pihak yang membantu.

\section{DAFTAR PUSTAKA}

Gilang, L., Sihombing, R. M., \& Sari, N. (2018). Pengaruh Konteks pada Ilustrasi Buku Pendidikan Karakter terhadap Perilaku Disiplin Anak Usia Dini. Scholaria: Jurnal Pendidikan Dan Kebudayaan, 8(1), 41-50.

Kementrian Lingkungan Hidup. (2018). Status Hutan \& Kehutanan Indonesia 2018. http://menlh.go.id

Kementrian Lingkungan Hidup. (2018). Strategi dan Rencana Aksi Konservasi Rangkong Gading (Rhinoplax vigil) Indonesia 2018-2028. http://menlh.go.id

Nuraida, D., \& Nisa, U. M. (2017). Pengembangan Ensiklopedia Morfologi, Anatomi dan Fisiologi pada Tumbuhan Berkarakter Khusus. Proceeding Biology Education Conference, 14, 503-507.

Nurgiyantoro, B. (2018). Sastra Anak Pengantar Pemahaman Dunia Anak. In UGM PRESS. UGM PRESS.

Rhett A. Butler. (2019). Pahlawan Konservasi: Wawancara dengan Rangkong Indonesia. Mongabay.

Samiudin. (2017). Pentingnya Memahami Perkembangan Anak Untuk. Pancawahana, 12(1), 1-9.

Sugiyono, P. D. (2019). Metode penelitian pendidikan:(pendekatan kuantitatif, kualitatif dan R \& D). ALFABETA.

Unaradjan, D. D. (2019). Metode Penelitian Kuantitatif. Unika Atma Jaya.

Yanty, R. H. K. C. B. T. A. I. I. M. R. (2017). Metodologi Penelitian. State Islamic University of Sunan Kalijaga Yogyakarta, 1(Metodologi Penelitian), 1-58. 